\title{
Do Universal Human Rights Equate to Varied Socio-Religious Backgrounds? Some Indigenous Perspectives
}

\author{
Muchammadun \\ Study Programme of Islamic Community Development \\ FDIK, State Islamic University of Mataram, Indonesia \\ muchammadun@uinmataram.ac.id
}

\begin{abstract}
Research on how universal human rights fit different socio-cultural settings still remains largely lacking. This paper sheds light under what understandings and circumstances universal human rights fit many socio-religious settings. It argues that human rights have been traditionally practices of many religions and culture yet need to further documented. Under intensive desk study and preliminary fieldwork, this research reveals two pivotal findings. First, the practice of human rights is not exclusively done by western countries yet it has been tied up with many socio-religious settings. Next, the universal values do not mean uniformity of cultural-based ideology. The findings imply that first, the values of Human rights are already universal and second, how the universal values are implemented in different settings of socio-religious cultures.
\end{abstract}

Keywords: human rights, cultural relativism, community well-being and development, interconnection

\section{INTRODUCTION}

Social Sciences, in the macro and mezzo levels, deal with policy challenges and collective practices for provision of human rights in different sociocultural settings. All of these are fundamental for community development and community well-being. However, human rights universality and its compatibility with Cultural Relativism is a longstanding topic of debate. The Universal Declaration of Human rights endorsement is criticized to violate the diversity of cultures in the world.

The main critique is that the concept comes from Western countries. In terms of faith and religion, for example, Wierzbicka (2018) states that the expression of God's anger or inter alia in Christian teaching, is actually not what is meant to be the Greek beorgizomai in its source language. There is a potential risk, therefore, that the translation will lead to distorted meaning transferred unless a commentary of how the concept is different is provided.

At the socio-religious praxis in Indonesia, James Bennett, at the July 2019 interview on the heated debate of syncretism and indigenous religions throughout Indonesia, believes that Dutch colonial period scholarship very much promoted the idea of Indonesian cultures as 'syncretic'. As an Islamic art historian, James argues contra that this Eurocentric view essentially served to portray the societies as somehow weakened in their original essence. Hence open to colonial improvement through 'Westernisation'. Such viewpoint developed out of the nineteenth-century view' of Java as a nation whose great Hindu-Buddhist past was weakened by Islam that never successfully gained a pure hold in Javanese society. Instead, they became adulterated through mixing (syncretisation) with the older HinduBuddhist traditions. The big problem is that Dutch scholars, even individuals like Snouke Hurgronje whose grasp of Islam was unsurpassed in the West in his time, did not have a clear understanding of the extent that so-called 'pure' Islam in the Middle East bore the imprint of an extremely syncretic historical past. One-sided view, is assumed to bring a risk of distorted meaning of translation unless attention to the insiders' views are regarded. Upon debating the Western notion of 'theatre', Nathalia Theodoridou from the school of Oriental and African Studies, London University, supports Bennett's reminder. In her distance-based interview reply, she analyses that Western-oriented views prove problematic to explain Balinese social practices. Therefore, she is wondering if scholarship can approach Balinese, representing other societies beyond the West, without awareness of cultural translation. These most contemporary concerns have echoed a number of scholars' views such as O'Byrne (2003) and Langlois (2012). They argue that Western cultural concept may not be compatible with that from other parts of the world. Hence, the endorsement of universal human rights is at risk of promoting Western cultural imperialism and hegemony.

This essay, however, argues that attempts to establish universal human rights do not equate to cultural imperialism. While the relativism of culture is recognized, this essay demonstrates that there are no direct implications of this for the validity of Human rights universality. Drawing upon scholarly papers from both sides, this claim will be mainly supported by two compelling reasons. First, human rights 
universality does not presuppose the endorsement of human rights uniformity. It means all cultures recognize values of human rights with possible different interpretation and practices at the implementation level. Hence, the real problem is not on the issue of cultural imperialism as the concept of human rights is already universal. Second, the debate emphasis should be more on the agreement of practices of Human rights and the implementation of human rights at different cultures.

\section{METHOD}

This essay employs a desk study, justified with some findings of preliminary fieldwork. Firstly, a set of qualitative and quantitative data related to the debate of universal human rights and cultural relativism are selected. This selection considers fair proportion of agreeing and disagreeing arguments on the promotion of the universality of human rights as well as relevant and updated data on human rights from different parts of the world. The main analysis, however, focuses on three related articles: Anthony J. Langlois' "Human rights" (2012), Jack Donnelly's "The Relative Universality of Human rights" (2007) and Daniel Bell's "The East Asian Challenge to Human rights: Reflections on an East-West Dialogue" (1996). Each argument will be noted and classified to see the logic, common ideas, and different views. Secondly, the collected data will be analysed to demonstrate each strength and weakness. A number of significant variables such as definitions, concepts, and case studies on human rights universality and cultural relativism will be drawn upon to support this paper synthesis which argues that the concept of human rights universality does not directly collide with the acknowledgement of cultural relativism.

Additionally, the successful promotion of the Universal Human rights can be well analysed from two perspectives. First, universal human rights must be differentiated from conceptual and practical perspectives. Second, the way they are translated from English to different languages of the world is important. Especially as the latter closely relates to language, two interviews with reputable linguistic Anthropologists were utilized to confirm my findings. One interview was a recorded interview with MIT's linguist Noam Chomsky who has spoken publicly about international politics and cultures. The recording was accessed on the Internet. The other one was conducted with Dr. Sarah Helcombe, who has translated the United Nations' Universal Declaration of Human rights into the central-Australian language of Pintupi-Luritja.

The paper proceeds in three sections. Section one will give an overview of the challenges involved in the promotion of universal human rights. Two differing views will be presented here. This debate is narrowed down in section two, where each perspective's strength and weakness will be analysed.
Section two is where main argument is mobilized. Accordingly, section three will conclude remarks and implications for the successful promotion of universal human right.

\section{CHALLENGES OF UNIVERSAL HUMAN RIGHTS}

\section{A. Two Differing Views}

The Universal Declaration of Human Rights promotes human rights, the rights that recognise human values, identity and ability to ensure an adequate living standard. The rights are "inalienable and applicable to all human beings" (Donnelly, 2007, p.282). This is an important base of human rights definition.

Throughout its development, human rights have already undergone three phases of development (Donnelly, 2007; Ife, 2001). Both Ife and Donnelly refer the first generation of human right to as liberally civil rights, including a political one. This definition is inherited by nature. The second generation of human rights deal with cultural, social and economic rights. This stage of human rights help achieve the community well-being and development as they concerns with how human in their senior citizenship is treated in dignity, adequate food and beverage as well as clothing are achieved as well as how rights of education and employment are somewhat guaranteed. The role of government is major here, making it the label of positive rights. The last human right generation is those at collective level. They belong to community at all levels. Some examples are the rights of unpolluted air to live in.

At the current context, a number of scholars believes that the Universal Declaration of Human Rights represent civil rights that must be universally applied. Donnelly (2003, p.22) for example, argues that the Universal Declaration of Human Rights is "the contemporary consensus on internationally recognized human rights". Hence, universal human rights are considered as values that are unaffected by any cultural or political variation.

The opposing view, however, considers the promotion of universal human rights as a new form of Western superiority, cultural imperialism. Drawing upon summaries of scholarly paper review, this opposing view is based on three compelling arguments: the problem of the establishment of universal human rights from their historical roots, the need from a number of developing countries to prioritize their economic development and political stability before establishing human rights, and criticism on human right promoters' inconsistent commitment to promote human rights.

In terms of human rights' historical root, Langlois (2009, p.12) argues that the origins of human rights are frequently linked to Western philosophy developed by Western philosophers such as John Locke. Culture on the other hand, is varied. Lucy 
(1992) cites Whorf's long-standing concept of cultural relativity which states that cultural practices of every society are inextricably linked with their cultural reality. As human rights values come from Western societies, the endorsement of human rights is therefore automatically inappropriate when assumed to apply to disparate cultures (Langlois, 2009, p.19). This idea derives from a philosophy of culture which holds that the way people conceptualize their world view is greatly influenced by their own language and culture (Saphir and Swadesh, 1946). O'Byrne (2003, p.42) supports such claim by demonstrating the Western concepts focus on individual emphasis and hence they can function as a "weapon of cultural hegemony" when imposed on other cultures. In other words, as human rights are believed to originate from Western concepts, their universal endorsement will violate other cultural values.

In addition to the objection about the origins of human rights, the challenge of reconciling human rights with cultural relativism is also hindered by the fact that human rights are difficult to establish in the absence of a baseline level of economic development and political stability. A number of research findings demonstrate that a strong economic and political foundation must be prioritized before the endorsement of universal human rights can be established. For example, Freeman (2008, p. 359) highlights that human rights are too expensive for poor countries. Hence, economic development must be prioritized. Such argument is supported by Ayittey (2011, p.18), who reveals the fact that strong economic growth of Asian Tigers was achieved in the climate of authoritarian governments. Bell's finding on South East Asian case studies (1996) also demonstrates a similar pre-caution. The study case shows that political stability and economic development are the first priorities before universal human rights can be established.

In relevance with the clash of human rights with economic priorities, a number of scholars also highlight how those who promote universal human rights often fail to practise them consistently. Adar (1998, 34-5) highlights that in situations where a conflict of interest emerges, the promoters of human rights do not behave consistently with the values of human rights. Western support to human rightsviolating regimes such as Mobutu and Selassie is a noteworthy example of this. This is what leads Amin (2004, p.78) to argue that the promotion of the human rights agenda only happens when it suits American interests.

The criticism of American inconsistency also comes from Noam Chomsky, one of America's most prominent political dissidents. Chomsky's main critique is on the flawed basis of cultural relativism. He argues that "In western discourse, when people talk about cultural relativism, it is about Asians, communists and others who do not accept some of the provisions of the Universal Declaration of Human rights" (National Human News and Analysis, 2015, para.4). In an illustrated cause and effect diagram, the challenges for universal human rights endorsement are as follows.

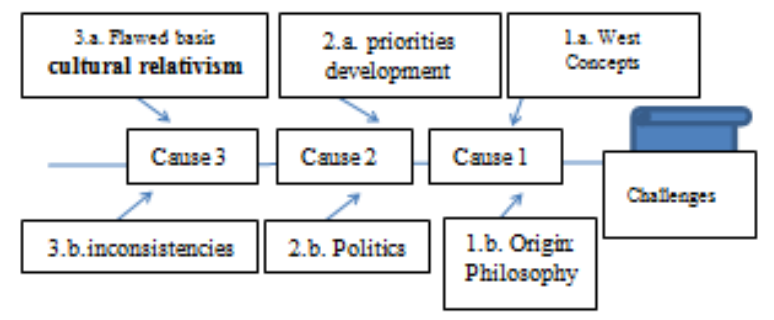

Note: Cause 1: History and philosophy Economic; 2. Economic and political priorities; 3 . Inconsistencies of human right practice.

Figure 1: Three main challenges preventing the promotion of universal human rights

Figure 1 above summarizes my argument to this point. It depicts the three main challenges preventing the promotion of human rights. The three factors on the top line and the three factors on the bottom line equally form each cause contributing to the challenges of universal human rights establishment. Each cause will be carefully analysed in the following section.

\section{B. Universality Does Not Mean Uniformity}

Having analysed the components of challenge of universal human rights to cultural relativism, it is easier to see each argument's validity. The following argument demonstrates each counter-argument to balance the issue of universal human rights.

To begin with, the cause 1 concerns with Western concepts and philosophy. However, Donnelly (2007) argues that the concept of human rights is found in many places all over the world and hence does not collide with the cultural relativism. Donnelly (2007, p.282-284) argues that human rights are universally inalienable. He (2007, p.282) argues that it is not only western culture that recognize essential civil rights that are entitled to all human beings. Donnelly demonstrates that throughout history, most societies and cultures have practised the values of human rights.

Albeit the Western concept of human rights, Islamic culture, for example, promotes the values of human rights such as fairness (al-adâlah), egalitarianism (al-musâwah), and freedom (alhurriyah). The concepts are clearly stated in the Koran, particularly in the verses of al-Hasyr: 7, anNisa': 135, al-Baqarah: 177. Furthermore, the value of human rights are relevantly stated in the concepts of human interaction such as Ukhuwah (QS. alHujurat [49]: 10), mutual cooperation (Ma'idah [5]: 2), reminder (al-, al-'Asr [103]: 3), encouragement, respects and tolerance stated in Ali Imran [3]: 104, 159, an-Nisa' [4]: 86, al-Mujadalah [58]: 11, ar-Ra'd 
[13]: 22-23, Ali Imran [3]: 133-135, dan al-Anfal [8]: 1.

More recently, civil rights can be simply referred to as presented in the Universal Declaration of Human rights. Its preamble states that it is to serve "as a common standard of achievement for all peoples and all nations." This implies that the Declaration is intended to be applicable universally. Hence, at the concept level, human rights values are universal in any culture. Wai (1979) also reminds us that the habit of traditional African societies to practice and support values of human rights is often neglected. Additionally, the recognition and practices of human rights are also an integral part of Asian culture and civilization (Ibrahim, 1994). This evidence shows that across time, history, and culture, the concept of human rights is universal. It is therefore very important to note that at the conceptual level, the universality of human rights is evident. The following two objections are basically at the implementation levels, which can be tackled one by one.

Additionally, another objection on universal human rights endorsement is due to concerns on political stability and economic development priorities. This shifts the human rights issue to a practical level. History has long noted that there is no single civilization and culture in the world consistently maintains the human rights with their politics. Donnelly, for example, cites that the ancient Greek also "practised slavery" and "denied the basic human rights to foreigners". The same case happens to medieval Europe where the egalitarianism of spiritualism and Christian universality was "deeply expressed in inegalitarian politics" (Donnelly, 2007, 286). In the modern world, Sen 1999, p. 248) demonstrates that seeing Asian values and history solely from a "narrow authoritarian values violates the rich varieties of thoughts in Asian intellectual traditions". These authors argue that inconsistent application of human rights can be found at all times, across the world.

Hence, human rights adoption throughout the word will be likely to succeed if promoters can develop significant bodies of human rights practices which suit the current condition. This can be assumed as the concepts of human rights are there already. For example, the human rights project led Dr. Sarah Helcombe, who manages a team of translators to translate the Declaration of Human rights into the central-Australian language of Pintupi-Luritja.

Taking care of specific culture-related issues such as the concept of collective societies in the indigenous society, Helcombe involves the stakeholders to gain their cultural values on human rights and to find some common values. Hence, in regard to philosophy of cultural specificity, whenever culturally specific terminology comes up, the direct translation into English is not applied. Rather, the description is made at the foot note. (Helcombe, 2015). Further, Helcombe argues that the Anglo key concepts of culture embodied in the translation of Human Right declaration embodies values that may be differently understood in the setting of local vernacular. Hence, the local knowledge and science need to be relevantly acknowledged.

More importantly, with widely understood shared human rights from stakeholders with different cultural background, the attitude toward human rights can come closer to agreement. At this point, all conflict of interests can be eliminated in such a way that there is mutual respects among states in the world, developing and developed countries. Conceptual universality of human rights can establish if the rights are equally held by all. This is an important issue to tackle objection cause 3 , where some parties suspect others to promote human rights only to take advantage of their conflict of interests.

Upon careful analysis of these challenges, the concepts of human rights are generally found with different practices of their implementation. It is therefore important to separate concepts and implementation. The claim of human rights universality at the conceptual level actually defends the human rights universality itself. However, the universality does not mean endorsement of western concept uniformity of practising human rights at the implementation levels.

\section{CONCLUSIONS}

The endorsement of the Universal Declaration of Human rights does not mean that it represents varieties of philosophical views and cultural differences. Rather, it relates to any commonalities among societies on ideals and aspirations of humanity. Evidence shows that there is a universal implication of human rights in all cultures; all humans are entitled to civil rights simply because they are human. By extension, human rights are universal. The concept of universal human rights, therefore, do not equate to cultural imperialism. Its universality does not mean uniformity nor can it imply imposition of Western norms on other cultures.

Furthermore, there must be an agreement by all states that despite the universal concept of human rights, the understanding and the implementation of the concept can be poly-interpretable. Hence, the translation of the Universal Declaration of Human rights leaves a problem of translating the culturally specific terminology into compatibility that is translatable across unrelated language and culture. The problem of Human rights Declaration in the indigenous language of Pintupi Lirutja noted in the case study may imply the same dilemma at other languages and cultures. This can be facilitated by the investigating the linguistic evidence of the researched language and leaving the non-direct translatable terminologies in the target language compensated with a footnote of 


\section{REFERENCES}

description. This will make sure that the Western concept is not forced and the equal standing of other cultures is treated. In other words, the adherence to human rights does not equate to means of cultural imperialism: getting people from other parts of the world do what Western states want. This will accelerate the success of developing the human rights values that are commonly shared among states in the world as well as bringing local identities to the same standing in the world.

Should agreement on universal concept of human rights be achieved, it could lead to mutual understanding in the more equal and fair relations in the global world. The understanding can be in the form of an international dialogue to map out problems of economic development and political stability from developing countries as well as conflicting interests from developed countries in relation to the maintenance of human rights. The universal human rights, by concept, can be implemented if they are equally held by all.

\section{ACKNOWLEDGMENT}

The author is credited with supports from Department of International Relations, Coral Bell School of Asia Pacific Affairs, The Australian National University College of Asia and Pacific for providing access of materials for macro community development studies, DFAT, the Australian government for funding provision and the school of Language, Linguistics and Literature, the ANU for directing my research paper to the field of macro social work and community education.
[1] Adar, K (1998) "The Wilsonian Conception of Democracy and Human rights: A Retrospective and Prospective", Journal of African Studies Quarterly, Vol.2, No.2, pp.33-44.

[2] Amin, S (2004), The Liberal Virus: Permanent War and the Americanization of the World, New York: Monthly Review Press.

[3] Ayittey, G (2011), Defeating Dictators: Fighting Tyranny in Africa and Around the World, Basingstoke: Palgrave Macmillan.

[4] Bell, DA (1996) "The East Asian Challenge to Human rights: Reflections on East-West Dialogue", Human rights Quarterly, Vol. 18, pp.641-667.

[5] Donnelly, J (2007) "The Relative Universality of Human rights", Human rights Quarterly, Vol. 29, pp.281-306.

[6] Dunstan M. Wai, MD (1979) "Human rights in Sub-Saharan Africa", in Adamantia Pollis \& Peter Schwab (eds). Human rights: Cultural and Ideological Perspectives, New York: Praeger, pp. 115, 116.

[7] Ife, J (2001) Human Rights and Social Work Towards Right Based Practice, Cambridge: Cambridge University Press.

[7] Freeman, M (2008) "Human rights" in P. Burnell and V. Randal; (eds.), Politics in the Developing World, Oxford: Oxford University Press, Chapter 18.

[8] Helcombe, S. The Universal Human rights Translation. Interview [20 September 2015].

[9] Humanitarian News and and Analysis (2015). Professor Noam Chomsky. http://www.irinnews.org/in-depth/59462/7/globalinterview-with-professor-noam-chomsky, [15 September 2015].

[10] Ibrahim, A (1994), "Rethinking Human rights", Special Address presented at the JUST International Conference, 7 Dec 1994, http://ikdasar.tripod.com/anwar/94-29.htm, [10 September 2015]

[11] Langlois, AJ(2012) "Human rights" in R Devetak, A Burke, and J George (eds), An Introduction to International Relations, Cambridge University Press: New York, pp.441-449.

[12] Langlois, AJ (2009) "Normative and Theoretical Foundations of Human rights" in M. Goodhart (ed.), Human rights: Politics and Practise, Oxford: Oxford University Press, Chapter 1.

[13] Lucy,AJ (1992) Language Diversity and Thought: A reformulation of the linguistic relativity hypothesis. Cambridge: Cambridge University Press.

[14] O’Byrne,D (2003), Human rights: An Introduction, Harlow: Pearson Education.

[15] Wierzbicka, A (2018) "Emotion of Jesus", Russian Journal of Linguistics, Vol. 22 No. $138-53$. 